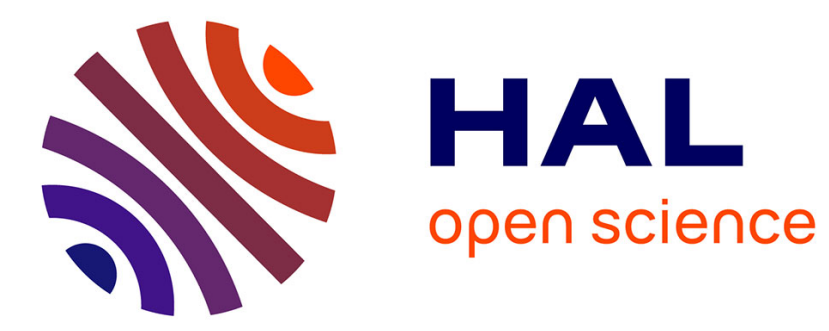

\title{
Characterization of Toxoplasma gondii isolates in free-range chickens from Portugal
}

J. P. Dubey, M. C. B. Vianna, Susana Sousa, N. Canada, S. Meireles, J. M. Correia da Costa, P. L. Marcet, T. Lehmann, Marie-Laure Dardé, P. Thulliez

\section{- To cite this version:}

J. P. Dubey, M. C. B. Vianna, Susana Sousa, N. Canada, S. Meireles, et al.. Characterization of Toxoplasma gondii isolates in free-range chickens from Portugal. Journal of Parasitology, 2006, 92 (1), pp.184-6. 10.1645/GE-652R.1 . hal-00351205

\section{HAL Id: hal-00351205 https://hal.science/hal-00351205}

Submitted on 3 Sep 2020

HAL is a multi-disciplinary open access archive for the deposit and dissemination of scientific research documents, whether they are published or not. The documents may come from teaching and research institutions in France or abroad, or from public or private research centers.
L'archive ouverte pluridisciplinaire HAL, est destinée au dépôt et à la diffusion de documents scientifiques de niveau recherche, publiés ou non, émanant des établissements d'enseignement et de recherche français ou étrangers, des laboratoires publics ou privés. 


\title{
Characterization of Toxoplasma gondii Isolates in Free-Range Chickens From Portugal
}

\author{
J. P. Dubey, M. C. B. Vianna, S. Sousa*, N. Canada†, S. Meireles`, J. M. Correia da Costa*, P. L. Marcetł, T. Lehmann $\ddagger$, M. L. Dardé§, \\ and P. Thulliez\|, U.S. Department of Agriculture, Agricultural Research Service, Animal and Natural Resources Institute, Animal Parasitic \\ Diseases Laboratory, Building 1001, Beltsville, Maryland 20705-2350; *Center for Parasite Immunology and Biology, INSA, Rua de S. Luis 16, \\ 4000-509 Porto, Portugal; †Institute for Biomedical Sciences Abel Salazar, Largo Abel Salazar, 24099-003 Porto, Portugal; $\neq$ Division of \\ Parasitic Diseases, Centers for Disease Control and Prevention, 4770 Buford Highway, Mississippi: F22, Chamblee, Georgia 30341; \\ §Laboratoire de Parasitologie-Mycologie, CHRU Dupuytren, 2, av Martin Luther King, 87042 Limoges cedex, France; ||Laboratoire de la \\ Toxoplasmose, Institut de Puériculture, 26 Boulevard Brune, F-75014, Paris, France; e-mail: jdubey@anri.barc.usda.gov
}

ABSTRACT: The prevalence of Toxoplasma gondii in free-ranging chickens is a good indicator of the prevalence of $T$. gondii oocysts in the soil because chickens feed from the ground. The prevalence of $T$. gondii in 225 free-range chickens (Gallus domesticus) from Portugal was determined. Antibodies to $T$. gondii were assayed by the modified agglutination test (MAT) and found in 61 chickens with titers of 1:5 in $8,1: 10$ in $6,1: 20$ in $3,1: 40$ in $23,1: 80$ in $5,1: 160$ in $4,1: 320$ in 8 , and 1:640 or higher in 4 . Hearts, leg muscles, and brains of 15 seropositive (MAT 1:10 or higher) chickens were bioassayed individually in mice. Tissue from 38 chickens with titers of 1:5 or less were pooled and fed to a $T$. gondii-free cat. Feces of the cat were examined for oocysts, but none was found. Toxoplasma gondii was isolated from 16 of 19 chickens with MAT titers of 1:10 or higher. Genotyping of 12 of these 16 isolates with polymorphisms at the SAG2 locus indicated that 4 were type III, and 8 were type II. None of the isolates was lethal for mice. Phenotypically, T. gondii isolates from chickens from Portugal were different from those of $T$. gondii isolates from chickens from Brazil.

Toxoplasma gondii infections are widely prevalent in human beings and animals worldwide (Dubey and Beattie, 1988). Humans become infected postnatally by ingesting tissue cysts from undercooked meat, consuming food or drink contaminated with oocysts, or accidentally ingesting oocysts from the environment. However, only a small percentage of exposed adult humans develop clinical signs. It is unknown whether the severity of toxoplasmosis in immunocompetent persons is due to the parasite strain, host variability, or other factors.

Toxoplasma gondii isolates have been classified into 3 genetic types (I, II, III) on the basis of restriction fragment length polymorphism (RFLP; Howe and Sibley, 1995; Howe et al., 1997; Mondragon et al., 1998; Owen and Trees, 1999; Feuntes et al., 2001; Grigg et al., 2001; Ajzenberg et al., 2002; Boothroyd and Grigg, 2002; Jungersen et al., 2002; Aspinall et al., 2003; Ajzenberg et al., 2004; da Silva et al., 2005). The parasite used to be considered clonal with very low genetic variability. However, most of the information was derived from isolates from Europe and North America. On the basis of newer markers for genetic characterization and with the use of recently isolated strains from Brazil and French Guiana, a higher genetic variability has been revealed than previously reported (Ajzenberg et al., 2004; Lehmann et al., 2004).

We have initiated a worldwide study of $T$. gondii population structure. For this purpose, we have chosen the free-range chicken as the indicator host for soil contamination with T. gondii oocysts because they feed from the ground. Thus far, we have characterized strains from South America (Brazil [Dubey et al., 2002; Dubey, Graham, da Silva et al., 2003; Dubey, Navarro et al., 2003; Dubey, Gennari et al., 2006], Peru [Dubey, Levy et al., 2004], Guatemala [Dubey, Lopez et al., 2005], Venezuela [Dubey, Lenhart et al., 2005], Argentina [Dubey, Venturini et al., 2003; Dubey, Marcet, and Lehmann, in press], Colombia [Dubey, Gomez et al., 2005]), the Caribbean (Grenada, West Indies; Dubey, Bhaiyat et al., 2005), North America (United States [Dubey, Graham, Dahl, Sreekumar et al., 2003; Lehmann et al., 2003], Mexico [Dubey, Morales, Lehmann, 2004]), Africa (Egypt [Dubey, Graham, Dahl, Hilali et al., 2003], Mali, Kenya, Burkina Faso, and Democratic Republic of Congo [Dubey, Karhemere et al., 2005]), Asia (Sri Lanka [Dubey, Rajapakse et al., 2005], India [Sreekumar et al., 2003], Israel [Dubey, Salant et al., 2004]), and Europe (Austria [Dubey, Edelhofer et al., 2005]). These studies are still not complete, and virulence in mice and genetic diversity have been examined in some detail only for the isolates from chickens from Brazil (Dubey et al., 2002; Dubey, Graham, da Silva et al., 2003; Dubey, Navarro et al., 2003; Dubey, Gennari et al., in press). Nevertheless, a pattern is emerging that indicates isolates from South America are genetically distinct (Lehmann et al., 2004).

In this study, we attempted to isolate $T$. gondii from chickens from Portugal. The chickens were from 18 small farms in rural areas of the country. Most properties were at least $500 \mathrm{~m}$ apart (Table I). Initially, 43 chickens (batch 1) were purchased, bled, and killed in Porto, Portugal; serum, heart, leg muscles, and brain from each chicken were sent cold by air to Beltsville, Maryland. Subsequently, serum samples from 182 chickens were tested for T. gondii antibodies at the Porto laboratory, and tissues from 34 serologically positive chickens (20 in batch 2, 10 in batch 3, and 4 in batch 4) were sent to Beltsville for bioassays. Five to 9 days elapsed between killing of chickens and receipt of samples.

Sera of chickens were tested for $T$. gondii antibodies with 2-fold serum dilutions from 1:5 to $1: 640$ by the modified agglutination test (MAT) as described by Dubey and Desmonts (1987). Tissues of chickens were bioassayed for $T$. gondii infection. Brains, leg muscles, and hearts of 5 chickens in batch 1 with MAT titers of 1:10 or higher were each bioassayed in out-bred female Swiss Webster mice obtained from Taconic Farms (Germantown, New York), as described by Dubey et al. (2002). Tissues were pooled, homogenized in saline, digested in acidic pepsin, and washed; the homogenate inoculated subcutaneously into 5 mice. Hearts, leg muscles, and brains from chickens in batch 3 were processed individually. Because tissues from batch 2 were spoiled during transit from Portugal to Beltsville, leg muscles were retained at the laboratory in Portugal and bioassayed in mice; pepsin digests were inoculated into 4 mice ( 2 mice were immunosuppressed with dexamethasone; Canada et al., 2002).

Tissues from 38 chickens with titers $<1: 5$ or less in batch 1 were pooled and fed to a $T$. gondii-free cat (Dubey et al., 2002). Feces of the cat were examined for shedding of $T$. gondii oocysts 3-14 days postingestion of the chicken tissues as previously described (Dubey, 1995). Fecal floats were incubated for $1 \mathrm{wk}$ at room temperature to allow sporulation of oocysts and were bioassayed in mice (Dubey and Beattie, 1988). Tissue imprints of mice that died were examined for $T$. gondii tachyzoites or tissue cysts. Survivors were bled on day 40-42 postinoculation (PI), and a 1:25 dilution of serum from each mouse was tested for T. gondii antibodies with the MAT. Mice were killed 45-48 days PI and brains of all mice were examined for tissue cysts as described (Dubey and Beattie, 1988). The inoculated mice were considered infected with $T$. gondii when tachyzoites or tissue cysts were found in tissues.

Toxoplasma gondii DNA was characterized from the tissues of a single infected mouse from each group (Lehmann et al., 2000). The RFLP strain type of $T$. gondii isolates was determined by nested PCR on the SAG2 locus according to Howe et al. (1997).

Antibodies to $T$. gondii were found in 61 chickens with titers of 1:5 in $8,1: 10$ in $6,1: 20$ in $3,1: 40$ in $23,1: 80$ in $5,1: 160$ in $4,1: 320$ in 8 , and 1:640 or higher in 4. Toxoplasma gondii was isolated from tissues of 16 chickens; from 5 of 5 chickens in batch 1 , none of 20 chickens from batch 2, 7 of 10 chickens from batch 3, and 4 of 4 in batch 4 . Of the 7 chickens in batch 3,T. gondii was isolated from the brain of 1 , brain and heart of 1 , hearts of 5 , and leg muscles of 5 (Table I). In batch $4 T$. gondii was isolated from the hearts of 2 , brain of 1 , and brain and heart of 1 . None of the mice inoculated from tissues of in- 
TABLE I. Isolation of Toxoplasma gondii from tissues of seropositive chickens from Portugal.

\begin{tabular}{|c|c|c|c|c|c|c|}
\hline Chicken no. & Household designation, location & $\begin{array}{l}\text { Chicken } \\
\text { MAT titer }\end{array}$ & \multicolumn{3}{|c|}{ Isolation in mice from chicken tissues* } & $\begin{array}{c}\text { Genotype (isolate } \\
\text { designation) }\end{array}$ \\
\hline 1 & Netos (Figueira da Foz) $40^{\circ} 14^{\prime} \mathrm{N}, 8^{\circ} 45^{\prime} \mathrm{W}$ & 80 & $5 / 5 \dagger$ & $\mathrm{n} / \mathrm{a} \dagger$ & $\mathrm{n} / \mathrm{a} \dagger$ & III (TgCkPr1) \\
\hline 3 & Mosteiró (Vila do Conde) $41^{\circ} 20^{\prime} \mathrm{N}, 8^{\circ} 42^{\prime} \mathrm{W}$ & 160 & $5 / 5 \dagger$ & $\mathrm{n} / \mathrm{a} \dagger$ & $\mathrm{n} / \mathrm{a} \dagger$ & III (TgCkPr3) \\
\hline 4 & Mosterió (Vila do Conde) $41^{\circ} 20^{\prime} \mathrm{N}, 8^{\circ} 42^{\prime} \mathrm{W}$ & 20 & $1 / 5 \dagger$ & $\mathrm{n} / \mathrm{a} \dagger$ & $\mathrm{n} / \mathrm{a} \dagger$ & II (TgCkPr4) \\
\hline 5 & Mosterió (Vila do Conde) $41^{\circ} 20^{\prime} \mathrm{N}, 8^{\circ} 42^{\prime} \mathrm{W}$ & 320 & $5 / 5 \dagger$ & $\mathrm{n} / \mathrm{a} \dagger$ & $\mathrm{n} / \mathrm{a} \dagger$ & III (TgCkPr5) \\
\hline 8 & (Albergaria-a-Velha) $40^{\circ} 41^{\prime} \mathrm{N}, 8^{\circ} 28^{\prime} \mathrm{W}$ & 640 & $0 / 5$ & $0 / 5$ & $4 / 4$ & II (TgCkPr8) \\
\hline 9 & (Albergaria-a-Velha) $40^{\circ} 41^{\prime} \mathrm{N}, 8^{\circ} 28^{\prime} \mathrm{W}$ & 640 & $0 / 5$ & $5 / 5$ & $4 / 4$ & II (TgCkPr9) \\
\hline 10 & (Albergaria-a-Velha) $40^{\circ} 41^{\prime} \mathrm{N}, 8^{\circ} 28^{\prime} \mathrm{W}$ & 640 & $0 / 5$ & $5 / 5$ & $4 / 4$ & II (TgCkPr10) \\
\hline 11 & (Albergaria-a-Velha) $40^{\circ} 41^{\prime} \mathrm{N}, 8^{\circ} 28^{\prime} \mathrm{W}$ & 80 & $5 / 5$ & $0 / 5$ & $0 / 4$ & II $($ TgCkPr11) \\
\hline 12 & (Albergaria-a-Velha) $40^{\circ} 41^{\prime} \mathrm{N}, 8^{\circ} 28^{\prime} \mathrm{W}$ & 320 & $0 / 5$ & $5 / 5$ & $0 / 4$ & II (TgCkPr12) \\
\hline 13 & (Barcelos) $41^{\circ} 32^{\prime} \mathrm{N}, 8^{\circ} 37^{\prime} \mathrm{W}$ & 160 & $5 / 5$ & $5 / 5$ & $\mathrm{ND} \ddagger$ & ND (TgCkPr13) \\
\hline
\end{tabular}

* (No. of $T$. gondii-positive mice)/(No. of mice inoculated).

$\dagger$ Mice were inoculated with pooled brain, heart, and leg muscle homogenates of chickens.

$+\mathrm{ND}=$ Not done

fected chickens became ill or died. The cat fed tissues of 38 seronegative chickens did not shed oocysts. Genotyping of the $12 \mathrm{~T}$. gondii isolates from chickens indicated that 8 were type II and 4 were type III; type I was not found.

In this study, $T$. gondii was isolated from all 5 seropositive chickens in the first batch, 0 of 20 chickens in batch 2, from 6 of 10 chickens in batch 3 , and 4 of 4 chickens in batch 4 . Attempts to isolate $T$. gondii from batch 3 of 20 seropositive chickens were not successful because the tissues had been stored at room temperature while in transit from Porto to Beltsville and were badly autolyzed; these data were not considered further.

Results of this limited study indicate that $T$. gondii isolates from Portugal are similar to those obtained from chickens from North America, Asia, and Africa and different from South American chicken isolates. The isolates from chickens from Asia, Africa, and North America were predominantly type II and type III and were not virulent for mice. Toxoplasma gondii genetic type prevalence and mouse virulence showed some heterogeneity among isolates from the chickens from South America studied so far. Seventy percent of $73 \mathrm{~T}$. gondii isolates from asymptomatic chickens from Brazil were type I, with no type II; type III mouse virulent isolates were present (Dubey et al., 2002; Dubey, Graham, da Silva et al., 2003; Dubey, Navarro et al., 2003). All isolates from chickens from Portugal were avirulent for mice.

The authors thank Nuno Gaspar, Andre Almeida, and Paulo Vieira for their assistance in obtaining free-range chickens.

\section{LITERATURE CITED}

Ajzenberg, D., A. L. Bañuls, C. Su, A. Dumètre, M. Demar, B. CarME, AND M. L. DARDÉ. 2004. Genetic diversity, clonality and sexuality in Toxoplasma gondii. International Journal for Parasitology 34: 1185-1196.

- N. Cogné, L. Paris, M.-H. Bessiéres, P. Thulliez, D. FilliSetti, H. Pelloux, P. Marty, and M.-L. Dardé. 2002. Genotype of 86 Toxoplasma gondii isolates associated with human congenital toxoplasmosis, and correlation with clinical findings. The Journal of Infectious Diseases 186: 684-689.

Aspinall, T. V., E. C. Guy, K. E. Roberts, D. H. M. Joynson, J. E. HydE, AND P. F. G. Sims. 2003. Molecular evidence for multiple Toxoplasma gondii infections in individual patients in England and Wales: Public health implications. International Journal for Parasitology 33: 97-103.

Boothroyd, J. C., AND M. E. GRIGG. 2002. Population biology of Toxoplasma gondii and its relevance to human infection: Do different strains cause different disease? Current Opinion in Microbiology 5: $438-442$.

Canada, N., C. S. Meireles, A. Rocha, J. M. Correia da Costa, M. W. ERICKSON, AND J. P. DUBEY. 2002. Isolation of viable Toxoplasma gondii from naturally-infected aborted bovine fetuses. Journal of Parasitology 88: 1247-1248.

da Silva, A. V., S. B. Pezerico, V. Y. de Lima, L. D’Arc Moretti, J. P. Pinheiro, E. M. TanaKa, M. G. Ribeiro, and H. Langoni. 2005. Genotyping of Toxoplasma gondii strains isolated from dogs with neurological signs. Veterinary Parasitology 127: 23-27.

Dubey, J. P. 1995. Duration of immunity to shedding of Toxoplasma gondii oocysts by cats. Journal of Parasitology 81: 410-415. , AND C. P. BEATTIE. 1988. Toxoplasmosis of animals and man. CRC Press, Boca Raton, Florida, 220 p.

—, AND G. DESmonts. 1987. Serological responses of equids fed Toxoplasma gondii oocysts. Equine Veterinary Journal 19: 337339.

- M. I. Bhaiyat, C. de Allie, C. N. L. Macpherson, R. N. Sharma, C. Sreekumar, M. C. B. Vianna, S. K. Shen, O. C. H. KWOK, AND T. LEHMANN. 2005. Isolation, tissue distribution, and molecular characterization of Toxoplasma gondii from chickens in Grenada, West Indies. Journal of Parasitology 91: 557-560.

$\longrightarrow$, R. Edelhofer, P. Marcet, M. C. B. Vianna, O. C. H. Kwok, AND T. LEHMANN. 2005. Genetic and biologic characteristics of Toxoplasma gondii infections in free-range chickens from Austria. Veterinary Parasitology 133: 299-306.

- S. M. Gennari, M. B. Labruna, L. M. A. Camargo, M. C. B. Vianna, P. L. MARCET, AND T. LeHMANN. 2006. Characterization of Toxoplasma gondii isolates in free-range chickens from Amazon, Brazil. Journal of Parasitology 92: 36-40.

- J. E. Gomez, A. Bedoya, F. Lora, M. C. B. Vianna, D. Hill, O. C. H. Kwok, S. K. Shen, P. L. Marcet, and T. Lehmann. 2005. Genetic and biologic characteristics of Toxoplasma gondii isolates in free-range chickens from Colombia, South America. Veterinary Parasitology 134: 67-72.

, D. H. Graham, C. R. Blackston, T. Lehmann, S. M. Gennari, A. M. A. Ragozo, S. M. Nishi, S. K. Shen, O. C. H. KwoK, D. E. Hill, AND P. Thulliez. 2002. Biological and genetic characterisation of Toxoplasma gondii isolates from chickens (Gallus domesticus) from São Paulo, Brazil: Unexpected findings. International Journal for Parasitology 32: 99-105.

—_ - - D. S. Da Silva, T. Lehmann, and L. M. G. BahiaOLIVEIRA. 2003. Toxoplasma gondii isolates from free ranging 
chickens from Rio de Janeiro, Brazil: Mouse mortality, genotype, and oocyst shedding by cats. Journal of Parasitology 89: 851-853.

, E. DaHL, M. Hilali, A. El-GHaysh, C. SREEKUMAR, O. C. H. KwoK, S. K. SHEN, AND T. LehmanN. 2003. Isolation and molecular characterization of Toxoplasma gondii from chickens and ducks from Egypt. Veterinary Parasitology 114: 89-95. C. SReekumar, T. Lehmann, M. F. Davis, AND T. Y. MorishITA. 2003. Toxoplasma gondii isolates from freeranging chickens from the United States. Journal of Parasitology 89: $1060-1062$

, S. Karhemere, E. Dahl, C. Sreekumar, A. Diabaté, K. R. Dabiré, M. C. B. Vianna, O. C. H. KwoK, AND T. LehMANn. 2005. First biologic and genetic characterization of Toxoplasma gondii isolates from chickens from Africa (Democratic Republic of Congo, Mali, Burkina Faso, and Kenya). Journal of Parasitology 91: $69-72$.

, A. Lenhart, C. E. Castillo, L. Alvarez, P. Marcet, C. SREEKUMAR, AND T. LeHMANN. 2005. Toxoplasma gondii infections in chickens from Venezuela: Isolation, tissue distribution, and molecular characterization. Journal of Parasitology 91: 1326-1331.

, M. Z. Levy, C. Sreekumar, O. C. H. Kwok, S. K. Shen, E. Dahl, P. Thulliez, And T. Lehmann. 2004. Tissue distribution and molecular characterization of chicken isolates of Toxoplasma gondii from Peru. Journal of Parasitology 90: 1014-1017.

- B. Lopez, M. Alveraz, C. Mendoza, and T. Lehmann. 2005. Isolation, tissue distribution, and molecular characterization of Toxoplasma gondii from free-range chickens from Guatemala. Journal of Parasitology 91: 955-957.

- , P. L. MARCET, and T. LehmanN. 2005. Characterization of Toxoplasma gondii isolates from free-range chickens in Argentina. Journal of Parasitology 91: 1335-1339.

, E. S. Morales, AND T. LEHMANN. 2004. Isolation and genotyping of Toxoplasma gondii from free-ranging chickens from Mexico. Journal of Parasitology 90: 411-413.

- I. T. Navarro, D. H. Graham, E. Dahl, R. L. Freire, L. B. Prudencio, C. SReekumar, M. C. Vianna, and T. Lehmann. 2003. Characterization of Toxoplasma gondii isolates from free range chickens from Paraná, Brazil. Veterinary Parasitology 117: 229234.

, R. P. V. J. Rajapakse, D. K. Ekanayake, C. SReekumar, and T. LEHMANN. 2005. Isolation and molecular characterization of Toxoplasma gondii from chickens from Sri Lanka. Journal of Parasitology 91: 1480-1482.

, H. Salant, C. Sreekumar, E. Dahl, M. C. B. Vianna, S. K. Shen, O. C. H. KwoK, D. Spira, J. Hamburger, and T. Lehmann. 2004. High prevalence of Toxoplasma gondii in a commercial flock of chickens in Israel, and public health implications of free-range farming. Veterinary Parasitology 121: 317-322.

, M. C. Venturini, L. Venturini, M. Piscopo, D. H. Graham, E. Dahl, C. Sreekumar, M. C. Vianna, and T. Lehmann. 2003. Isolation and genotyping of Toxoplasma gondii from free-ranging chickens from Argentina. Journal of Parasitology 89: 10631064.

Fuentes, I., J. M. Rubio, C. Ramírez, And J. Alvar. 2001. Genotypic characterization of Toxoplasma gondii strains associated with human toxoplasmosis in Spain: Direct analysis from clinical samples. Journal of Clinical Microbiology 39: 1566-1570.

Grigg, M. E., J. Ganatra, J. C. Boothrooyd, and T. P. Margolis. 2001. Unusual abundance of atypical strains associated with human ocular toxoplasmosis. Journal of Infectious Diseases 184: 633-639.

Howe, D. K., AND L. D. Sibley. 1995. Toxoplasma gondii comprises three clonal lineages: Correlation of parasite genotype with human disease. Journal of Infectious Diseases 172: 1561-1566.

- S. Honoré, F. Derouin, ANd L. D. Sibley. 1997. Determination of genotypes of Toxoplasma gondii strains isolated from patients with toxoplasmosis. Journal of Clinical Microbiology 35: 14111414.

Jungersen, G., L. Jensen, M. R. Rask, And P. Lind. 2002. Non-lethal infection parameters in mice separate sheep type II Toxoplasma gondii isolates by virulence. Comparative Immunology, Microbiology and Infectious Diseases 25: 187-195.

Lehmann, T., C. R. Blackston, S. F. Parmley, J. S. Remington, and J. P. Dubey. 2000. Strain typing of Toxoplasma gondii: Comparison of antigen-coding and house-keeping genes. Journal of Parasitology 86: $960-971$

, D. H. Graham, E. Dahl, L. M. G. Bahia-Oliveira, S. M. GENNARI, AND J. P. DubEY. 2004. Variation in the structure of Toxoplasma gondii and the roles of selfing, drift, and epistatic selection in maintaining linkage disequilibria. Infection, Genetics and Evolution 4: 107-114

, - C. SReekumar, F. Launer, J. L. Corn, H. R. Gamble, and J. P. Dubey. 2003. Transmission dynamics of Toxoplasma gondii on a pig farm. Infection, Genetics and Evolution 3: 135-141.

Mondragon, R., D. K. Howe, J. P. Dubey, and L. D. Sibley. 1998. Genotypic analysis of Toxoplasma gondii isolates from pigs. Journal of Parasitology 84: 639-641.

Owen, M. R., AND A. J. TReEs. 1999. Genotyping of Toxoplasma gondii associated with abortion in sheep. Journal of Parasitology 85: 382384.

Sreekumar, C., D. H. Graham, E. Dahl, T. Lehmann, M. Raman, D. P. Bhalerao, M. C. B. Vianna, And J. P. Dubey. 2003. Genotyping of Toxoplasma gondii isolates from chickens from India. Veterinary Parasitology 118: 187-194.

\section{Helminth Assemblages of the Turtle Emydura macquarii (Pleurodira: Chelidae) Queensland, Australia}

Meryl A. Ferguson and Lesley R. Smales*, School of Biological and Environmental Sciences, Central Queensland University, Rockhampton, Queensland, 4702, Australia; *corresponding author. e-mail: I.warner@cqu.edu.au

ABSTRACT: The helminth fauna of 76 Emydura macquarii from 3 river systems in central and northern Queensland was examined. Eleven species were found, including 2 nematodes, 6 trematodes, 1 aspidogastrean 1 cestode, and 1 monogenean. Analysis of helminth diversity showed that the Fitzroy and Ross River turtles had communities of comparable diversity, but the helminth communities in Proserpine River turtles were much less diverse. The helminth communities in all localities were dominated by trematodes. Polystomoides australiensis was the most prevalent, being found in $60 \%$ of the Ross River turtles, $57 \%$ of the Fitzroy River turtles, and $46 \%$ of the Proserpine River turtles. Notopronoce- phalus peekayi was the most abundant species, with mean abundances of 5.9 in the Ross River turtles and 9.8 in the Fitzroy River turtles. Species richness, Simpson's Reciprocal Index, was highest, 4.68, for the Ross River helminth community, Sorensen's Qualitative Index showed 95\% similarity between the Ross River and Fitzroy River communities, although Sorensen's Quantitative Index indicated only 35\% similarity between the 2 sites. Host feeding patterns are likely the most important factor affecting species richness of the helminth infracommunities, as the majority of helminth species are transmitted by food-web interactions involving intermediate hosts. 
Emydura macquarii (Gray, 1830) is a member of the Pleurodira, turtles characterised by sideways flexion of the neck vertebrae during head retraction. This group of turtles is limited to freshwater environments in the southern hemisphere and is the remnant of a much larger group with a cosmopolitan distribution. Emydura is 1 of 5 genera of chelid turtles currently recognized from Australia. Recent work by Georges and Adams (1996) has placed 2 of the previously accepted species, E. krefftii Gray and E. signata Ahl from north Queensland and northern New South Wales, as synonyms of E. macquarii. Prior to this change, E. krefftii was recognized in the north and E. macquarii in the southern region below Bundaberg $\left(24^{\circ} 52^{\prime} \mathrm{S}, 152^{\circ} 21^{\prime} \mathrm{E}\right)$ (Georges and Adams, 1996). Emydura macquarii prefers slow flowing water and is mostly omnivorous, though juveniles and breeding females are predominantly carnivorous (Cogger, 1996).

The previously recorded helminths of E. macquarii include 2 nematodes (Ferguson and Smales, 1998), 5 monogeneans (Rohde and Pearson, 1980; Rohde, 1984; Pichelin, 1995), 11 digeneans (Platt and Pichelin, 1994; Platt and Blair, 1996; Cribb and Pichelin, 1997; Jue Sue and Platt, 1998a, 1998b; 1999; Ferguson et al. 2001; Platt and Brooks, 2001; Platt, 2003), and 1 aspidogastrean (Ferguson et al. 1999).

In the present study, we examined the helminths occurring in E. macquarii collected from north and central Queensland. Three coastal waterways, Ross River ( $\left.19^{\circ} 16^{\prime} \mathrm{S}, 146^{\circ} 49^{\prime} \mathrm{E}\right)$, Proserpine River $\left(20^{\circ} 24^{\prime} \mathrm{S}\right.$, $\left.148^{\circ} 35^{\prime} \mathrm{E}\right)$, and Fitzroy River $\left(23^{\circ} 22^{\prime} \mathrm{S}, 150^{\circ} 32^{\prime} \mathrm{E}\right)$, were sampled for $E$. macquarii between 1994 and 1998. One turtle from the Gordonvale River $\left(16^{\circ} 45^{\prime} \mathrm{S}, 145^{\circ} 47^{\prime} \mathrm{E}\right)$, and 1 from the Burnett River $\left(24^{\circ} 52^{\prime} \mathrm{S}\right.$, $\left.152^{\circ} 21^{\prime} \mathrm{E}\right)$ were also examined.

Turtles were collected using drum nets, crab pots, or hand lines baited with ox heart. Following capture, turtles were held in freshwater in fiberglass tanks for no more than $24 \mathrm{hr}$ before killing by cervical injection of an overdose $\left(>5 \mathrm{ml} / \mathrm{kg}\right.$ bodyweight) of Nembutal ${ }^{\circledR}$ (pentobarbitone sodium). Carcasses were dissected and all internal organs, eyes, mouth, and body cavity examined for helminths. On removal, all worms were washed in $0.7 \%$ saline. Nematodes were fixed in hot formalin. Trematodes were relaxed in $0.1 \%$ ethanol and fixed by pipetting into near-boiling formalin. Cestodes were relaxed in tap water then fixed in formalin. All helminths were identified to species level.

The prevalence and mean abundance, as defined by Bush et al (1997), of each species of helminth were determined for each locality. Specialist and generalist species were assigned according to Kennedy (1995). Species richness was calculated using Simpson's Reciprocal Index (1/D). Sorenson's Qualitative (presence/absence), and Quantitative (abundance) Indices (Magurran, 1988) were used to measure similarity between the helminth communities from each locality.

The SPSS 10 statistical package was used for calculations, and unless otherwise specified, significance levels are at $0.05(5 \%)$. All work for this project was carried out under CQU Animal Ethics Clearance No. 95/7-105. All collections were performed under Environmental Protection Agency Permit Nos H0/000119/95/SAA, N0/001662/97/SAA, and C6/000077/98/SAA. All material was deposited in the South Australian Museum.

In total, 78 E. macquarii, 37 males and 41 females, were collected and 11 species of helminths were identified (Table I). The most common group was the Digenea, with 5 genera from 4 families. The Aspidogastrea, Monogenea, and Cestoda were each represented by a single species and the Nematoda by 2 species from 2 families. Nine species, Choanocotyle elegans Jue Sue and Platt, 1998, C. nematoides Jue Sue and Platt, 1998, Aptorchis aequalis Nicoll, 1918, Notopronocephalus peekayi Cribb and Pichelin, 1997, Pretestis laticaecum Ferguson, Cribb, and Smales, 2001, Sigmapera cincta Nicoll, 1918, Sychnocotyle kholo Ferguson, Cribb, and Smales, 1999, Camallanus chelonius Baker, 1983, and Spiroxys chelodinae Berry, 1985 were found in the intestine. Of these, S. kholo, Si. Cincta, and C. chelonius occupied the same habitat, the region immediately posterior to the stomach. Polystomoides australiensis Rohde and Pearson, 1980 was found in the accessory bladders, and Gigantolina elongata (Johnston 1931) was free in the body cavity.

The prevalences and mean abundances of the helminth species from each locality are summarized in Table I. Polystomoides australiensis, $S$. $k h o l o$, and $N$. peekayi were the most prevalent and $N$. peekayi was the most abundant in the host population (Table I). No helminth species was found in all turtles and 3 (i.e., A. aequalis, $P$. australiensis, and $S$. kholo) were found in all 3 localities. Pretestis laticaecum was the only
TABLE I. Prevalence \% (P) and mean abundance (A) of 11 helminth species found in Emydura macquarii from 3 localities in Queensland.

\begin{tabular}{|c|c|c|c|c|c|c|}
\hline & Ross & River & $\begin{array}{r}\text { Pros } \\
\mathrm{R}\end{array}$ & $\begin{array}{l}\text { pine } \\
\text { er }\end{array}$ & Fitzroy & River \\
\hline \multirow[t]{2}{*}{ Number of hosts } & 15 & & 10 & & 51 & \\
\hline & $\mathrm{P}$ & A & $\mathrm{P}$ & A & $\mathrm{P}$ & A \\
\hline \multicolumn{7}{|l|}{ Digenea } \\
\hline Choancotyle elegans & 13 & 0.2 & - & - & 2.0 & 0.02 \\
\hline Choancotyle nematoides & 13 & 0.3 & - & - & 2.0 & 0.02 \\
\hline Aptorchis aequalis & 27 & 0.8 & 30 & 1.7 & 25 & 3.2 \\
\hline Sigmapera cincta & 20 & 3.8 & - & - & 33 & 4.0 \\
\hline Pretestis laticaecum & - & - & - & - & 6 & 0.6 \\
\hline \multicolumn{7}{|l|}{ Notopronocephalus } \\
\hline peekayi & 33 & 5.9 & - & - & 41 & 9.8 \\
\hline \multicolumn{7}{|l|}{ Aspidogastrea } \\
\hline Sychnocotyle kholo & 53 & 2.0 & 10 & 0.6 & 49 & 1.3 \\
\hline \multicolumn{7}{|l|}{ Monogenea } \\
\hline $\begin{array}{r}\text { Polystomoides } \\
\text { australiensis }\end{array}$ & 46 & 0.7 & 60 & 0.8 & 57 & 0.8 \\
\hline \multicolumn{7}{|l|}{ Amphilinidea } \\
\hline Gigantolina elongata & - & - & 10 & 0.1 & - & - \\
\hline \multicolumn{7}{|l|}{ Nematoda } \\
\hline Camallanus chelonius & 66 & 3.7 & - & - & 16 & 0.4 \\
\hline Spiroxys chelodinae & 20 & 0.4 & - & - & 35 & 0.8 \\
\hline
\end{tabular}

specialist helminth (i.e., occurring only in E. macquarii.) Two species, Ch. nematoides and Pr. laticaecum, also occur in other species of Emydura. The remaining 8 species were generalist parasites of the Chelidae. No additional species were found in the Gordonvale and Burnett River hosts.

The Fitzroy River community, with 10 helminth species, had the highest species richness, followed by 9 from the Ross River community and 4 from the Proserpine River community. Simpson's Reciprocal Index (I/D) was highest for the Ross River community with an I/D of 4.68 (15 hosts), followed by the Fitzroy community with an I/D of 3.48 (51 hosts), and lowest for the Proserpine River community with an I/D of 2.77 (10 hosts). Comparison of the Ross River and Fitzroy River communities using Sorenson's Qualitative Index showed 95\% similarity, and these 2 communities had 55\% and $43 \%$ similarity with the Proserpine River community, respectively. Sorenson's Quantitative Index, however, indicated that similarity was low for all sites; only $6 \%$ similarity between the Fitzroy and Proserpine River communities, $17 \%$ similarity between the Proserpine and Ross River communities, and $35 \%$ similarity between the Ross and Fitzroy River communities. There was a significant difference in the number of helminth species in hosts from each area (ANOVA, $F_{270}=5.440, P=0.006$ ). An a posteriori Tukey pairwise comparison test showed that the Proserpine River community had significantly fewer species than the Ross River and Fitzroy River communities.

Data from each of the localities were pooled across time and must, therefore, be treated with caution; nevertheless some observations about the helminth communities at each location can be made. Of the 11 helminth species present, only 4 occurred in turtles from the Proserpine River. Although the sample size from both the Ross River and Proserpine River turtles was small (15 and 10 individuals) compared to the Fitzroy River sample (51), only a single additional helminth species was recovered from the Fitzroy River sample. The low number of helminths recovered from the Proserpine River may, therefore, be indicative of a small available pool of species, rather than the small sample size. Plagiorchiids dominated the community in terms of abundance (Table I), even though S. kholo (aspidogastrid) and P. australiensis (monogenean) were more prevalent. Only 1 species of pronocephalid was recorded. In contrast, Cribb and Pichelin (1997) reported 3 species occurring in E. macquarii from southern Queensland. No spirorchiids 
were recovered from this community, though they were expected, as Platt and Pichelin (1994) reported 1 species from southern Queensland, and Platt and Blair (1996) reported 2 species from northern Queensland The choanocotyliid, Auriculotrema lechneri, found in northern chelids by Platt (2003), was not seen in this study.

In E. macquarii, 9 of the 11 helminths reported (Table I) are transmitted via dietary items. Four species use tadpoles, snails, or the occasional crayfish as hosts of infective stages (Jue Sue and Platt, 1998a, 1998b, 1999). Two species employ copepods as intermediate hosts, together with a variety of aquatic species (snails, tadpoles, frogs, and fish) as potential paratenic hosts (Anderson, 2000). One species uses a parastacid crayfish (Rohde and Georgi, 1983), another has a snail (Ferguson et al. 2001) as an intermediate host, and 1 encysts on algae (Angel and Manter, 1970). The only active colonizer among the parasites is $P$ australiensis (Rohde and Pearson, 1980); in this case, the infective stage swims to the turtle host. There is no life cycle information available for $N$. peekayi. This suggests that the structure of the helminth community is influenced by host feeding patterns. Molluscs and algae form a large proportion of the diet of E. macquarii, although other food items are eaten if available (Cogger, 1996). Such opportunistic feeding habits are congruent with this notion. Consequently infection would be random, dependant on both the availability of particular foods and their selection by the turtle host

The communities of helminths in the Fitzroy and Ross Rivers were the most similar, with 9 species in common, whereas that in the Proserpine River had significantly fewer species. Random factors, i.e., the availability of infected food items and the food choices of the host, as indicated above, appear to be the determinants of the poor species richness found in the Proserpine River helminth community.

Potential species richness was never realized in any of the individual hosts or host populations. Of the 11 species found in this study, the greatest number of species in any 1 host was 6 . The total number of species recorded for E. macquarii in Queensland is 19, and approximately $60 \%$ of these species were recovered in the present study. The findings in the present study are consistent with the conclusion of Bush et al. (1990) that the habitat of the host is an important determinant of species richness, and that the helminth infracommunities of $E$. macquarii are most likely the product of random or stochastic events (Esch and Fernandez, 1993; Poulin, 1996).

We thank Tom Cribb, Sylvie Pichelin and Steve McKillup for their assistance with analyses and critical comments.

\section{LITERATURE CITED}

ANDERSON, R. C. 2000. Nematode parasites of vertebrates: Their development and transmission, 2nd ed. CABI Publishing, Wallingford, U.K., $650 \mathrm{p}$.

Angel, L. M., And W. H. Manter. 1970. Pretestis australianus gen. et sp. nov. (Digenea: Paramphistomatidae) from Australian fish, and a closely related cercaria, Cercaria acetabulapapillosa sp. nov. with notes on the life history. Serie Zoologia 1: 1-10.

Bush, A. O., J. M. Aho, And C. R. Kennedy. 1990. Ecological versus phylogenetic determinants of helminth parasite community richness. Evolutionary Ecology 4: 1-20.

, K. D. Lafferty, J. M. Lotz, and A. W. Shostak. 1997. Parasitology meets ecology on its own terms: Margolis et al. revisited. Journal of Parasitology 83: 575-583.

Cogger, H. G. 1996. Reptiles and amphibians of Australia, 5th ed. Reed Books, Chatswood, Australia, 796 p.

CRiBb, T. H., AND S. PiCHELIN. 1997. Notopronocephalus peekayi gen. et sp. n. (Digenea: Pronocephalidae) from Australian freshwater turtles. Folia Parasitologica 44: 279-282.

Esch, G. W., AND J. C. FERnANDEZ. 1993 A functional biology of parasitism. Ecological and evolutionary implications. Chapman Hall, London, U.K., 337 p.

Ferguson, M. A., And L. R. Smales. 1998. Spiroxys chelodinae Berry, 1985 (Nematoda: Spiruroidea) and Camallanus chelonius Baker,
1983 (Nematoda: Camallanoidea) from freshwater turtles (Pleurodira: Chelidae) in Queensland, Australia. Transactions of the Royal Society of South Australia 122: 185-189.

, T. H. CRIBB, AND L. R. SMALES. 1999. Life cycle and biology of Sychnocotyle kholo n. g., n. sp. (Trematoda: Aspidogastrea) in Emydura krefftii (Pleurodira: Chelidae) from southern Queensland, Australia. Systematic Parasitology 43: 41-48.

, L. R. Smales, And T. H. CRIBb. 2001. A new species, Pretestis laticaecum, (Trematoda: Cladorchiidae), from Emydura krefftii Gray, 1871 (Pleurodira, Chelidae) from central Queensland, Australia. Transactions of the Royal Society of South Australia 125: 123-127.

Georges, A., AND M. AdAms. 1996. Electrophoretic delineation of species boundaries within the short-necked freshwater turtles of Australia (Testudines: Chelidae). Zoological Journal of the Linnean Society 118: $241-260$.

Jue Sue, L., And T. R. Platt. 1998a. Redescription and life-cycle of Sigmapera cincta Nicoll, 1918 (Digenea: Plagiorchiidae) a parasite of Australian freshwater turtles. Systematic Parasitology 39: 223235.

, AND - 1998b. Description and life-cycle of two new species of Choanocotyle n. g. (Trematoda: Plagiorchiida), parasites of Australian freshwater turtles and the erection of the family Choanocotylidae. Systematic Parasitology 41: 47-61.

, AND . 1999. Description and life-cycle of three new species of Dingularis n. g. (Digenea: Plagiorchiidae), parasites of Australian freshwater turtles. Systematic Parasitology 43: 175-207.

KENNEDY, C. R. 1995. Richness and diversity of macroparasitic communities in tropical eels Anguilla reinhardtii in Queensland, Australia. Parasitology 111: 233-245.

Poulin, R. 1996. Richness, nestedness, and randomness in parasite infracommunity structure. Oecologia 105: 545-551.

MagurRAN, A. E. 1988. Ecological diversity and its measurement Chapman \& Hall London, U. K., 179 p.

Pichelin, S. 1995. The taxonomy and biology of the Polystomatidae (Monogenea) in Australian freshwater turtles (Chelidae, Pleurodira). Journal of Natural History 29: 1345-1381.

Platt, T. R. 2003. Description of Auriculotrema lechneri n. gen., n. sp. (Digenea: Choanocotylidae), a parasite of freshwater turtles (Testudines: Pleurodira: Chelidae) from Queennsland, Australia. Journal of Parasitology 89: 141-144.

, AND D. BLAIR. 1996. Two new species of Uterotrema (Digenia Spirorchidae), a parasite of the freshwater turtle Emydura macquarii from southern Queensland, Australia. Journal of Parasitology 82: $307-311$.

, AND D. R. BROOKS. 2001. Description of Buckarootrema goodmani n. g., n. sp. (Digenea: Pronocephalidae), a parasite of the freshwater turtle Emydura macquarii (Gray, 1830) (Pleurodira: Chelidae) from Queensland Australia, and a phylogenetic analysis of the genera of the Pronocephalidae Looss, 1902. Journal of Parasitology 87: 1115-1119.

- AND S. PICHELIN. 1994. Uterotrema australispinosa n. gen., n. sp. (Digenea: Spirorchidae), a parasite of a freshwater turtle Emydura macquarii from southern Queensland, Australia. Journal of Parasitology 80: 1008-1011.

RoHDE, K. 1984. Two amphistomes, Lobatodiscus australiensis n. g., n. sp. and Elseyatrema microacetabularis n. g., n. sp., from the Australian turtle Elseya dentata (Gray). Systematic Parasitology 6: 219-227.

, AND M. GeORGi. 1983. Structure and development of Austram philina elongata Johnston, 1931 (Cestodaria: Amphilinidea). International Journal for Parasitology 13: 273-287.

, AND J. C. PEARson. 1980. Two polystomes (Monogenea) from Australian river tortoises (Pleurodira, Chelidae); Polystomoides australiensis sp. nov. from Emydura krefftii, and Neopolystoma chelodinae (MacCallum, 1919) from Chelodina longicollis. Zoologicher Anzeiger 204: 191-208. 